\title{
The Accessibility of Informal Urban Women Workers (Study of Street Vendors in Malang, Indonesia)
}

\author{
Diyah Ayu Amalia Avina ${ }^{1}$ \\ ${ }^{1}$ Lecturer, Social and Political Faculty, University of Brawijaya, Malang, Indonesia \\ Correspondence: Diyah Ayu Amalia Avina, Lecturer, Social and Political Faculty, University of Brawijaya, Malang, \\ Indonesia.
}

Received: February 28, 2017

doi:10.11114/ijsss.v5i5.2350
Accepted: March 29, $2017 \quad$ Available online: April 12, 2017

URL: https://doi.org/10.11114/ijsss.v5i5.2350

\begin{abstract}
The effort to increase people's welfare through empowerment of informal woman workers to increase household income becomes interesting and important to do it. The empowerment of informal woman workers has important roles to decrease unequal distribution income and give substantial contribution for overcome the problem of unemployment. However, although woman had given income in the family, the man dominates the decision-making of the household rules. The accessibility should be directly proportional to the decision-making in the household rules.

The purpose of this research is for 1) to analyze the motivation of informal urban woman worker, 2) to analyze the experience of woman worker, 3) to analyze education, 4) to analyze the capital of the worker, 5) to analyze the urban informal decision-making in the household rules. This research did in Malang. The population of this research is 1000 street vendors in Malang. Then, the sampling is taken using Random Sampling Method. The sample of this research consists of 24 respondents of street vendors. The result of the research is between motivation of work, work experience, and the fund are positively related to accessibility and the decision-making in the household rules have not high accessibility. It is due to very strong culture of patriarchy in society.
\end{abstract}

Keywords: woman, informal worker, accessibility

\section{Introduction}

\subsection{Background}

In the wider society and especially for family, a woman has to educating, taking care, and be role model for her children. Actually, women also contribute in the public sector to run the economic sector. There are multiple roles of woman in a family in general, as a homemaker and work. The urban woman had many jobs to earn money as real potential and as active participation human resources.

One of the serious problems still faced by urban communities and also in rural is poverty that forced each family ultimately to work hard and work together in this regard is the father and the mother. In urban areas, the population of woman reaches $53 \%$. Woman's gait to come forward starting open widely by the growth of woman in grab every available opportunity to search for the source of income.

Nici Nelson found more women with restrictiveness than men in the selection of its economic activity so that the informal sector is often as women's choices, since the informal sector is accessible rely on their own local resources. The over plus of informal sector as a relaxing for their activities job opportunity become interesting alternative for wo man in order to earn income. Many informal economic activities did by women by consider time allocation for family and workdays of household.

The result of the various research showed that business activity in the informal sector, especially in the sectors of trade can be expected to support the household economy (Jafar, 1994; Widaningroem; Sunaryo, and Djasmani, 1992; Subarsono, 1998; Soetrisno, 1999). Thus, the efforts to improve the well-being of the community through empowerment of woman merchants of the informal sector in order to increase household income be interesting and important to do. In addition, the empowerment of woman traders the informal sector has important roles to reduce the inequality of income distribution and provide a major contribution in tackling the issues of unemployment (Gilbert and Gugler, 1996). 


\subsubsection{Formulation of the Problem}

1. Is there any relation between the motivation of woman labor with woman accessibility in the informal sector in the city of Malang?

2. Is there any relation between the experiences of the woman labor with woman accessibility in the informal sector in the city of Malang?

3. Is there any relation between education of the woman labor with woman accessibility in the informal sector in the city of Malang?

4. Is there any relation between the capital of woman labor with woman accessibility in the informal sector in the city of Malang?

5. How does the pattern of decision-making informal sector woman labor in the household in the city of Malang?

\subsubsection{Research Objectives}

1. To analyze relation between the motivation of woman labor with woman accessibility in the informal sector in the city of Malang.

2. To analyze relation between the experience of the woman labor with woman accessibility in the informal sector in the city of Malang.

3. To analyze relation between the education of the woman labor with woman accessibility in the informal sector in the city of Malang.

4. To analyze relation between the fund of the woman labor with woman accessibility in the informal sector in the city of Malang.

5. To analyze the patterns of decision-making in the household of the woman labor in the urban informal sector in the city of Malang?

\subsubsection{Output/External}

The expected output of this research is to know how gender relations influence the accessibility against the labor of woman in productive work on street's vendor in Malang. In addition, this research will give knowledge about the construction of perspective gender and critical awareness-raising for woman to actively participate in the development of the productive effort.

\section{Review of Literature}

\subsection{Theoretical Basis}

\subsubsection{Gender}

According to Oakley (Fakih, 1996:71) that gender is a concept that refers to the difference in behavior between man and woman who are socially constructed, that is not the nature but created by human beings. According to Parson (Ritzer, 1984:456) that function of family effectively is the family with the existence of a sexual division of work, where man and woman have very different roles.

According to the concept of gender that characteristics owned by the man and woman who construction the social cultural and based on biology giving rise to the general values which are considered the nature of the man and woman are as follows.

If based this concept, only three biologically characteristics of woman nature, that is pregnant, give birth, and lactating. These third characteristics are not nature but the construction of social culture that considered the nature characteristics are from God. 


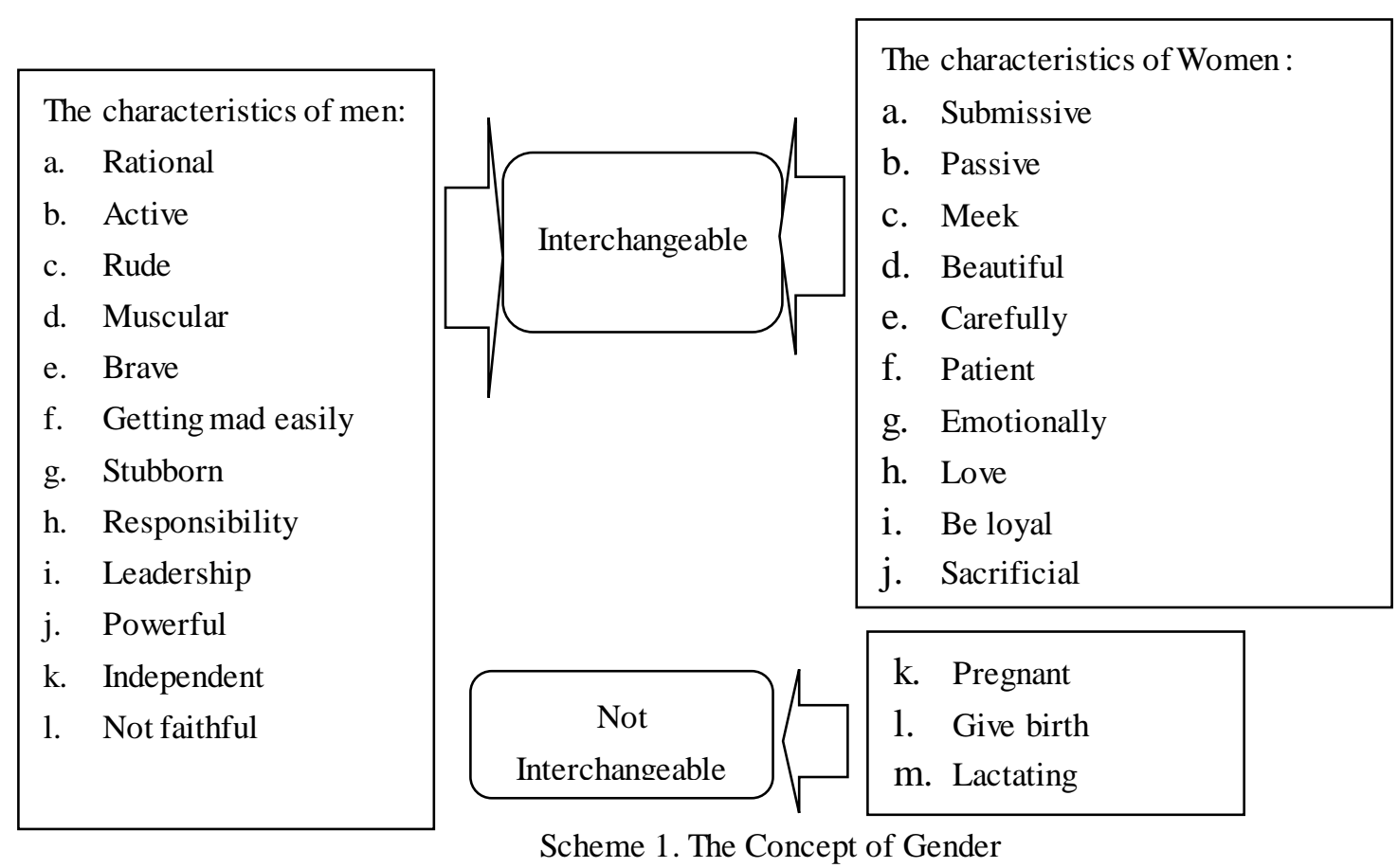

Sources: Mansour Faqih

\subsubsection{Motivation}

According to Stokes (1966) in Kadarisman (2012:278) motivation is as the stimulation for someone to do the job better, and a factor of difference between success and failure, as well as the emotional energy for a new job. The core purpose of motivation is to improve spirit, productivity and efficiency with so performance will increase.

\subsubsection{Experience}

The length of time an entrepreneur to do their business will affect the ability of professionalism, the longer devoted will also increase knowledge of consumers, and skill of marketing become increasingly their sophisticated. In addition, successful business relations get more and more.

\subsubsection{Education}

Education is learning the knowledge, skills, and habits of a group of people that are passed down from one generation to the next through teaching, training, or research. Education is one of the indicators of the quality of human resources. According to Becker (1993:29) education is a process of investment activities that improve skills (investment in human capital). In Law Number 20 in 2003 Article 13 paragraph 1. explain the educational consists of Formal Education, Informal Education, and Non formal Education.

\subsubsection{Capital}

Capital is the amount of money spent on entrepreneurs to set up and operate a business. Capital directly related to income level. The relatively greater capital allows a unit of economic activity adding to the variation of the merchandise. Based on the source, the capital is dividing into two types, namely, Capital Loans and Private Capital.

\subsubsection{Accessibility}

The word is derived from the United Kingdom accessibility, which means convenience. Accessibility is the degree of ease by people toward an object, service or environment. The length of operation time of informal trade business have a direct relation with the level of income. Long hours will provide an opportunity to reach bigger turnover. It also means the more increase revenues.

\subsubsection{The Pattern of Decision-Making}

Each individual in taking decisions and actions have al ways been influenced by other members. Every individual in the organization (household or community) is always tied to specific culture and norms which guide and direct them in doing the action or decision-making. The factors that affect the level of effort decision-making are the purpose, knowledge and engagement, as well as environmental factors. 


\subsubsection{The Informal Trade Sector}

According to Kuncoro (2003), the informal sector is business units which very get little attention from the government. This informal sector consists of small-scale business units (small capital, manpower of households, and simple technology) that produces and distributes goods and services with the aim of subject matter to create employment opportunities and income for himself and each of his attempts were very limited by capita, both human and physical, as well as skills.

\subsection{Hypothesis}

The hypothesis presented in this research is as follows.

1. There is relationship between Motivation, Experience, Education, and Capital with Accessibility for woman in the informal sector.

2. There is relationship between Motivation, Experience, Education, and Capital with Accessibility for woman in the street's vendor informal sector.

\section{Research Methodology}

\subsection{Research Approach}

Based on the formulation of the problem and research objectives, methodology/research approach used is quantitative research. This research did by taking samples from a population and use questionnaires as a main of collecting the data, then did analyzing data to explain the causal relationships between variables through hypothesis testing.

\subsection{Research Methods}

The method based on numerical information or quantities, and usually associated with statistical analysis. The survey usually runs by spreading question form/questionnaire to respondents. In the context of research, the researchers will share a questionnaire to street vendors in Malang with random sampling techniques.

\subsection{Operational Definition}

In this study, there are two variables which underlying the research, they are variable (X) and variable (Y).

1. The variable $\mathrm{X}$ is also called the free variable (Independent Variable) that is allegedly as the cause or the predecessor of other variables. In this research, free variable is Venture Capital, Motivation, Education, and Experience.

2. The variable $\mathrm{Y}$ is also called with the dependent variable (Dependent Variable) that is allegedly as a result of or influenced by variables that preceded it. In this study, dependent variable is accessibility.

\subsection{Validity And Reliability Tests}

1. Validity Test

Validity is a measure that shows the levels of validity or the correctness of an instrument. The validity of intended to reveal the extent of how far the instrument will be measure and what is the instrument wants to be measured (Kriyantono, 2012).

\section{Reliability Test}

Reliability means that it has something to be believed. In other words, a measuring instrument has a reliability measurement when results are relatively consistent when it is used repeatedly by other researchers on different time (Kriyantono, 2012).

\subsection{The Sampling Technique}

The population in this study is the street vendors who are consist of 1000 traders. Later, the technique of gathering the data is use random sampling. The sample in this study consists of the 24 respondents street vendors.

\subsection{Data Collection Techniques}

The technique of data collection in this research is use questionnaire. In this research, the questionnaire is used to collect data about the relation of gender with the labor women's accessibility. The procedure for giving score to answer of the questionnaire is given to the respondents to question which is a statement that will be calculated from the sample.

\subsection{Data Analysis Technique}

The data analysis technique that is used in this research is a statistical analysis using simple linear rank correlation model of the Pearson product moment correlation or to know the relationship of the independent variable, the relation of motivation, experience, education, and capital (X) with bound variable to the accessibility of the labor women (Y). 


\section{Results and Discussion}

\subsection{Instrument Test of Research}

\section{Validity Test}

Validity is a measurement that indicates the level of valid or correctness of an instrument. An instrument is said to be valid if it is able to measure what is wanted (Arikuntto, 1998:160). To test the validity of the measuring instrument can be carried out with the method of person correlation / product moment. The way is correlate each score to the total of the items in each variable research. When the correlation value (r-count) is greater than $r$-tables or their significance values smaller than the alpha $5 \%$ then it can be said to be valid.

Table 1. Validity Test

\begin{tabular}{cccc}
\hline No & Indicator & The Validity Coefficient & Description \\
\hline 1 & X1.1 & 0,516 & Valid \\
2 & X1.2 & 0,681 & Valid \\
3 & X1.3 & 0,759 & Valid \\
4 & X2.1 & 0,464 & Valid \\
5 & X2.2 & 0,528 & Valid \\
6 & X2.3 & 0,602 & Valid \\
7 & X3.1 & 0,693 & Valid \\
8 & X3.2 & 0,632 & Valid \\
9 & X3.3 & 0,610 & Valid \\
10 & X4.1 & 0,744 & Valid \\
11 & X4.2 & 0,514 & Valid \\
12 & X4.3 & 0,712 & Valid \\
13 & Y.1 & 0,702 & Valid \\
14 & Y.2 & 0,595 & Valid \\
\hline
\end{tabular}

Source: SPSS Output Processing

For $n=4$, the value of $r$ table is 0,404 . If the value of the correlation coefficient is greater than 0,404 and numbers of significance smaller than 0,05 instrument indicators data is said to be valid. From the table above, note that the validity of the test indicator X 1.1 until indicator Y. 1 is valid, because $r$ count greater than $r$ table 0,404 and less than 0,05 significance of the numbers.

\section{Reliability Test}

Reliability is a tool that gives you the same results (consistent). Measurement results should remain the same (relative) if the measurement is given on the same subject though it is done by different people, different time and different place. The method that is used to test reliability is Cronbach's Alpha. Reliability coefficient of reliability said if alpha is greater than the value of the index alpha 0,6 .

Table 2. Reliability Test Output (Reliability Statistics)

\begin{tabular}{cc}
\hline Cronbach's Alpha & N of Items \\
\hline .938 & 15 \\
\hline
\end{tabular}

\section{Source: SPSS Output}

On the SPSS output are known to value Cronbach's Alpha is 0,938 where this value is larger than the alpha index 0,6 . The results show that the data is reliability.

\subsection{Analysis of The Hypothesis Test Results With Pearson Correlation}

Analysis results used in this research is the Pearson correlation analysis. This analysis is used to measure the relationship between two variables. The values of correlation range is from -1 to 1 , where the value of the correlation of -1 means the relationship between two variables is negative relationship, while a value of 0 means there is no relationship between the two variables, and a value of 1 means that there is a positive relationship between the two variables. The higher value of the correlation of the high relationship is between the two variables.

Correlation analysis used in this research is the analysis of the Pearson correlation to find out the relationship between the variable data of the interval scale, the ratio (numeric), and normal distribution. To find out if the correlation value is significant, it needs to be determined numbers of significance. In this research, the number of significance used 0,05 with confidence level of $95 \%$. So the significance relationship of the two variables can be analyzed with the certainty if the significance $<0,05$, so can be said that relationship of two variable is significant, so that $\mathrm{H} 0$ is rejected and the $\mathrm{H} 1$ is accepted.

In this study, the correlation of test results of each variable $\mathrm{X}$ with $\mathrm{Y}$ variable can be seen in the table listed below: 
Table 3. 17 Pearson Correlation Test

\begin{tabular}{llllll}
\hline No & Variable & r score & r table & Sig & Alpha \\
\hline 1 & Motivation (X1) & 0,774 & 0,404 & 0,000 & 0,05 \\
2 & Experience (X2) & 0,669 & 0,404 & 0,000 & 0,05 \\
3 & Education (X3) & 0,745 & 0,404 & 0,000 & 0,05 \\
4 & Capital (X4) & 0,743 & 0,404 & 0,000 & 0,05 \\
\hline
\end{tabular}

Source : SPSS Output Processing

In this research, the correlation analysis was used to see the power of a second variable relationship, the significance of relationship, and the direction of the relationship.

\section{Hypothesis Test Between Motivation (X1) and Accessibility (Y)}

On Pearson correlation tests' table, the correlation coefficient of Pearson ( $\mathrm{r}$-woman) variable $\mathrm{X} 1$ is 0,774 . The correlation coefficient numbers showed that the relationship between Motivations with Accessibility is a very strong relationship.

The significance relationship of the motivation with accessibility can be analyzed by looking at the numbers of significance in SPSS output that have been processed and presented in table test correlation Pearson. In the tables, numbers of significance is 0,00 . It can be concluded that $0.00<0,05$, so relationships between motivation and accessibility for woman labor in the informal trade sector is significant and $\mathrm{H} 1$ are accepted.

The correlation's direction shows the correlation number of views. The results of the correlation coefficient are the motivation 0,774 which shows the coefficient is positive, so the direction of the relationship of motivation and accessibility is unidirectional. This means that if the motivation is high, then the accessibility will also be high.

\section{Hypothesis Test Between Experience (X2) and Accessibility (Y)}

Pearson correlation coefficient numbers ( $r$ count) variable $\mathrm{X} 2$ is 0,669 . The correlation coefficient numbers showed that the relationship between experiences with accessibility is strong relationships.

In Pearson correlation test, on a number of variable significance of the experience is 0,00 . From the figure it can be analyzed that $0,00<0,05$, so relationships of experience and accessibility for woman labor in the informal trade sector is significant and $\mathrm{H} 1$ are accepted.

The result of the correlation coefficient is the experience 0,669 which shows the coefficient is positive, so the direction of relationship of experience with accessibility is unidirectional. If someone's experience is high, then the accessibility will also be high.

\section{Hypothesis Test Between Education (X3) and Accessibility (Y)}

The Pearson correlation coefficient numbers ( $\mathrm{r}$ count) variable $\mathrm{X} 3$ is 0,745 . The correlation coefficient numbers showed that the relationship between educations with accessibility is a very strong relationship.

The significance numbers of variable on the education's table test correlation is $0,00<0,05$, so relationships education and accessibility for woman labor in the informal trade sector significant and $\mathrm{H} 1$ are accepted.

The correlation's direction shows the correlation number of views. The result of the correlation coefficient is the coefficient indicating 0,745 positive, so that the direction of the relationship of education and accessibility is unidirectional. If a person's level of education is high, then the accessibility will be high as well.

\section{Hypothesis Test Between Capital (X4) and Accessi bility (Y)}

The Pearson correlation coefficient numbers ( $r$ count) on Pearson correlation tests of the table is 0,743 . The correlation coefficient numbers showed that the relationship between the capital and accessibility is very strong.

The significance of the relationship between the capital and accessibility can be known of the significance of the variable capital 0.00 on table test of Pearson correlation of less than 0.05 or $0.00>0.05$. The results show that the capital relationship with accessibility for woman labor in the informal trade sector is significant, so the H1 is accepted.

Based on the results of the correlation coefficient of the test table on the motivation of the Pearson's correlation coefficients, 0.743 shows that the coefficient is positive, so, the direction of relationship capital with accessibility for women in the informal trade sector is unidirectional. That is, if the capital is high, then the accessibility for women in trade will also be high.

4.3 Analysis

Traders feel more motivated to earn income to meet family needs. The more the number of families more needs to be achieved. So that more and more families greater the motivation to earn more revenue. Due to the high motivation to 
earn income women then traders will override social structure and achieve access to work.

Highly motivated influenced to earn more revenue. One way to get a lot of revenue is discipline in work. Workers in Indonesia usually start opening stores from morning 03.00 because the morning market in Indonesia visited by many customers. This morning markets provide fresh vegetables, fruit and other household commodities.

At the morning market getting morning store opened more and more customers. The number of customers has influence to gain revenue. More and more customers are increasingly increases the motivation to earn income. The fewer customers are increasingly making motivation to work down.

Trader woman who has long worked as a trader has extensive experience related to her job. It makes easier for women traders in conducting its work. It makes in expanding access to more revenue.

Women workers usually do not just do one job only. If it has many of the skills they will have a lot of variation job. In the morning working as a trader then daylight to enter professions such as farmers or baker if there are orders. The more the capabilities of women can give wider accessibility in the work. So it's important for women to have an education and a good skill to have wide access to work and earn income is used to meet family needs.

Female workers who have long worked in the plane will have a lot of experience. This experience can help many women traders to avoid bankruptcy and to increase business potential. So that wider access to do a lot of business activities.

Women workers in Indonesia have a very central role. In addition to acting as a housewife who take care of housekeeping. One role is managing family finances. So that women who clearly understands the needs of families. If the husband income is not able to meet the needs of families, women will go to work to meet the needs of families.

The amount of capital owned by a female worker has an influence on the level of accessibility, es pecially social capital. The more social capital is stronger then women workers in doing the work have broad access. So that women who have a strong capital to develop access to employment and increase revenue.

Women have a limited working time. They have responsible to manage the house need too. However, women workers who have access to a strong outside of work as housewives have ample opportunity in career advancement and access to jobs.

So it can be ensured for women who have a high income means having high accessibility. The results showed that the higher the accessibility of the higher female labor income.

\section{Conclusions and Suggestions}

\subsection{Conclusions}

1. Motivation of work related positive with accessibility. Seen from the results of a correlation value 0,774 which means there is a connection between the work's motivation with accessibility. There is a very strong relationship with the significance level less than alpha 0,05. Traders feel motivated to earn a high income if you have a number of dependents that much. Meanwhile, work motivation is apparent from the time workers started their work activities, The morning in starting trading activities, continued to show a high motivation. Number of customers affects the motivation of female workers. The more working women have the higher motivation accessibility.

2. Work experience related positive with Accessibility. Seen from the results of a correlation value 0,669 which means there is a relationship between work experiences with accessibility. There are strong relationships with significance levels of less than alpha 0,05. This shows that the longer experience of female workers in the field that was involved increasingly have the greater accessibility.

3. Education related positive with accessibility. Seen from the results of a correlation of 0,745 which means there is a relationship between work experiences with Accessibility. There are strong relationships with si gnificance levels of less than alpha 0,05 . It shows that education have a strong influence in determining the accessibility of female workers. So the training has benefits in increasing accessibility.

4. Capital related positive with accessibility. Seen from the results of a correlation value 0,743 that means there is a relationship between work experiences with Accessibility. There is a very strong relationship with the extent of significance of less than alpha 0,05 . The amount of capital determines the acces sibility of particular income.

5. Decision making patterns of women's labor in the informal sector in the household does not have a high accessibility. Man or in this case is the husband still has a central role for each policy in the household. So, the woman in this case involved a husband wife in any decision making. It is because still condensed Patriarchy culture in the midst of the community. In addition, it is because still low awareness of gender and knowledge that exist in society. 


\subsection{Suggestions}

Suggestions from the researcher it is conducting outreach about the understanding of gender and training for the community. It is useful to add the knowledge about gender and training attitude in order to make appear the balance and no longer occur the refraction of gender.

It needs to be studied further using qualitative methods what caused the accessibility of women in the informal sector do not affect significantly the decision making patterns in the household.

\section{References}

Arikunto, S. (1998). Prosedur Penelitian Suatu Pendekatan Praktek. Jakarta: PTRineka Cipta.

Becker, G. S. (1993). Human Capital, A Theoretical and Empirical Analysis with Special Reference to Education, Third Edition. The University of Chicago Press. https://doi.org/10.7208/chicago/9780226041223.001.0001

Fakih, M. (1996). Analisis Genderdan Transformasi Sosial. Yogyakarta: Pustaka Pelajar Offset.

Gilbert, A. D. J. G. (1996). “Urbanisasi dan kemiskinan di dunia ketiga” pengantar: DR. Nasukin. Yogyakarta: PT. Tiara Wacan Yogya.

Kadarisman, M. (2012). Manajemen Pengembangan Sumber Daya Manusia, Rajawali Pers, Jakarta.

Kriyantono, R. (2012). Teknik Praktis Riset Komunikasi Disertai Contoh Praktis Riset Media, Public Relations, Advertising, Komunikasi Organisasi, Komunikasi Pemasaran. Jakarta: Prenada Media.

Kuncoro, M. (2003). Ekonomi Pembangunan: Teori, Masalah, dan Kebijakan. Yogyakarta: UPPAMP_YKPN.

Parson, T. (1964). The Social System. New York: Free Press.

\section{Copyrights}

Copyright for this article is retained by the author(s), with first publication rights granted to the journal.

This is an open-access article distributed under the terms and conditions of the Creative Commons Attribution license which permits unrestricted use, distribution, and reproduction in any medium, provided the original work is properly cited. 